\title{
Comparison of Production Performance and Physical Quality of Quail Eggs (Coturnix-coturnix japonica) Fed with Kangkung (Ipomoea reptans Poir.) Seed Meal and its Fermentation Product
}

\section{Astuti Kusumorini ${ }^{1,2 *}$, Ramadhani Eka Putra ${ }^{3}$, Ana Rochana ${ }^{1}$, Denny Rusmana ${ }^{1}$}

${ }^{1}$ Faculty of Animal Science, Padjajaran University. Bandung-Sumedang Street 12km, Jatinangor, Sumedang 45363, West Java, Indonesia; ${ }^{2}$ Departmen of Biology, Faculty of Science and Technology, The State of Islamic University of Sunan Gunung Djati of Bandung. Bandung, Indonesia, 40611; ${ }^{3}$ School of Life Sciences and Technology, Institut Teknologi of Bandung, Bandung, Indonesia, 40132.

\begin{abstract}
In poultry industry, feed has been considered as the most important component in term of energy and cost which caused a huge burden for small-scale farmers. On the other hand, many industries produce significant number of organic wastes which could be utilize as substitute for poultry feed. In this study, broken kangkung seed (Ipomoea reptans Poir) (KS), a byproduct seed company, and its fermentation product (KSF) were applied as part of rations for quail (Coturnix-coturnix japonica) and the effect on the eggs production and quality were observed. The study was conducted with a completely randomized design method with 4 ration namely R1 (0\% KS/KSF), R2 (7,5\% KS/KSF), R3 $(15 \% \mathrm{KS} / \mathrm{KSF})$, and R4 (22,5\% KS/KSF) and replicated 5 times (each replication consisted of 12 of 30-days old quails). The parameters observed were production performance: daily egg production (\%), daily egg mass (grams), egg weight (grams), and egg quality: Haugh unit, shell thickness, shape index, albumen index, yolk index, and yolk color. The results showed KSF meal increased egg production around 37.35\%, egg mass 5.94\%, egg weight 5.40\%, and decreased feed conversion $13.79 \%$. Based on the mean value of each parameter, KS meal had a better effect on the yolk color, yolk index, and shape index while KSF meal increased the albumen index value, shell thickness, and haugh unit.
\end{abstract}

Keywords | Kangkong seeds, Fermentation, Egg quality, Egg production, Quail

Received | May 26, 2021; Accepted | July 10, 2021; Published | August 25, 2021

*Correspondence | Astuti Kusumorini, Faculty of Animal Science, Padjajaran University. Bandung-Sumedang Street 12km, Jatinangor, Sumedang 45363, West Java, Indonesia; Email: astuti16001@mail.unpad.ac.id

Citation | Kusumorini A, Putra RE, Rochana A, Rusmana D (2021). Comparison of production performance and physical quality of quail eggs (Coturnix-coturnix japonica) fed with kangkung (Ipomoea reptans Poir.) seed meal and its fermentation product. Adv. Anim. Vet. Sci. 9(10): 1616-1624.

DOI | http://dx.doi.org/10.17582/journal.aavs/2021/9.10.1616.1624

ISSN (Online) | 2307-8316; ISSN (Print) | 2309-3331

Copyright $(\odot 2021$ Kusumorini et al. This is an open access article distributed under the Creative Commons Attribution License, which permits unrestricted use, distribution, and reproduction in any medium, provided the original work is properly cited.

\section{INTRODUCTION}

$\mathrm{G}$ lobal demand for poultry meat and eggs increases along with the increasing human population, economic growth, and public awareness of the importance of health (Zadeh et al., 2019). The growth period of quail is an important phase for good performance and product quality (Elnesr et al., 2019). Fish meal is still used as the main source of poultry feed to meet protein needs, because it contains high protein and easily digested by the body and contains essential amino acids, especially sulfur-containing amino acids, namely lysine which has high biological value in physiological and metabolism of poultry. because the price is still expensive, thus increasing costs for feed (FAO, 2013). It is necessary to do some research to replace a fish meal with other ingredients without a negative impact on the performance of poultry.

Quail is widely used for meat and eggs in many regions, especially Asia, namely China and India, and Europe, namely Spain and France (Bertechini, 2012; El-Daly et al., 2013). Quail has a small size, fast growth, and high level of productivity, quail is very suitable to be developed on a small scale as well as large-scale commercial production 
(Shanaway, 1994). There is no information and data regarding the statistical data on quail egg production in the world because it is often combined with other poultry, but some data notes that the production of quail from several countries in the world is quite significant (Kumari et al., 2008). In 2008 Japan produced 5.9 million eggs from 112 farms and China in 2009 reported a population of laying quails reach 300 million (da Cunha, 2009). Meanwhile in Indonesia, the population continues to increase, in 2016 the population was around 13,932,649 quails and in 2020 increase to $14,819,755$ quails Directorate General of Livestock and Animal Health (2020).

The aspect used to measure egg quality is physical characteristics such as shell thickness, egg shape, egg weight, and other factors that support consumer preferences in choosing eggs is yolk color. The quality of the eggs needs to be improved to meet consumer standards. Many studies have been conducted to improve egg quality such as the feed manipulation method (Sugiura et al., 2009).

Eggs are an important component in food, able to meet $13 \%$ of the daily protein needs of adults and $25 \%$ of children. Also, it contains essential nutrients for vital functions such as lipids, vitamins, and minerals (Grela et al., 2014). According to Bologa et al. (2013), some egg quality in terms of chemical, physical and biological value is influenced by many factors such as species, laying conditions, storage processes, and feed ingredients. In this context, the substitution of feed ingredients can change the quality of animal products, to produce eggs with good quality in terms of physical and nutritional content.

Quail eggs are one of the most efficient sources of animal protein with an average weight of 6-16g (Sezer, 2007). According to Kumai et al. (2008), the composition of quail eggs contains $56.83 \%$ albumin, $34.61 \%$ egg yolk, and 8.56\% eggshell. Quail eggs are rich in amino acids and minerals such as calcium, phosphorus, and iron (Tolik et al., 2014). Japanese quail farming offers the potential for world meat and egg production, because of its high protein quality and low calories in meat and eggs when compared to other poultry (Runjaic et al., 2010; El-Daly et al., 2013).

According to Machal and Simeonovová (2002), with the increasing age of quail, egg production will decrease, egg weight increases, and the composition and thickness of the shell changes. The increase in egg weight ratio can be up to $20 \%$. However, there was no proportional increase in shell weight because calcium was distributed over a wider shell surface. Old laying quail absorbs less calcium due to reduced calcium retention in the intestine and increased bone calcium mobilization, leading to the production of eggs with thinner or more fragile shells.
Quail feed consists of several types of feed ingredients, including protein sources such as fish meal and soybean meal, which are still relatively expensive. According to the Directorate General of PPHP (2014) in 2013, Indonesia has imported more than 3.53 million tons of soybean meal. This condition will continue in line with the increase in the poultry population every year. This is a challenge for researchers to explore finding other feed ingredients as a cheaper feed substitute, has abundant availability, and does not compete with human needs. Waste-based feed or waste product has recently been studied for poultry feed ingredients, especially waste that still contains sufficient protein. However, no one study has used kangkong seeds as a feed ingredient.

Kangkung is a vegetable favored by the population of many Asian countries, with high demand, automatically its seeds will be produced continuously and produce a waste product that available throughout the year. The waste of kangkong seeds contains $13.46 \%$ crude protein and $16 \%$ crude fiber whose quality can still be improved by fermentation. According to Aro (2008) fermentation is a technology often used in modifying the biological value of a material to increase protein and reduce anti-nutrients as well as crude fiber. Thus, this comparative study of feed ingredients aims to obtain cheap feed ingredients with good quality.

\section{MATERIALS AND METHODS}

\section{SOURCES AND PREPARATION OF RAW MATERIALS}

Land spinach seeds used in this study originated from a local seed factory. The seeds then dried under the sun for 3 days or until the weight was constant. Dried seed then grounded with a disk mill machine to produce the kangkung seed meal (KS) $(0.87 \mathrm{~mm}$ in diameter in average $)$ (Benedetti et al., 2011) (Figure 1).

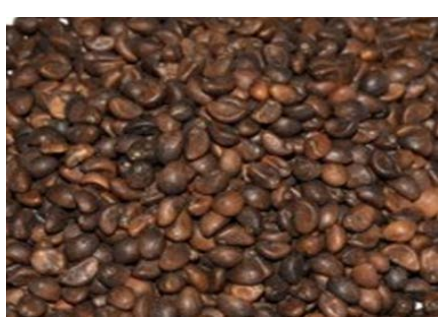

Biji kangkung kualitas bagus (Mangkoko, 2015)

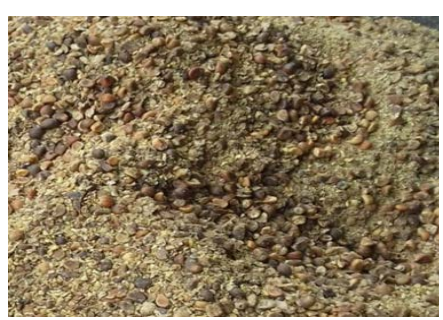

Limbah biji Kangkng
Figure 1: Kangkong seed and grounded kangkong seed.

\section{THE FERMENTATION PROCESS OF KANGKONG SEED}

Kangkong seed meal was steamed for 30 minutes then cooled under room temperature. About 100 grams of KS was kept inside the plastic bag and watered until all powder was homogenously wet then dried at room temperature. 
The Rbizopus oligosporus fungus inoculated with the dosage of 0.3 gram / 100 grams of material and kept for 72 hours at room temperature (average temperature $27^{\circ} \mathrm{C}$ and $\mathrm{rH}$ $80 \%)$. The process was conducted until all KS covered by hypha of R. oligosporus (Figure 2). The fermented product (kangkong seed meal fermentation, KSF) were kept inside refrigerator (average temperature $3^{\circ} \mathrm{C}$ ) prior utilization as part of ration.

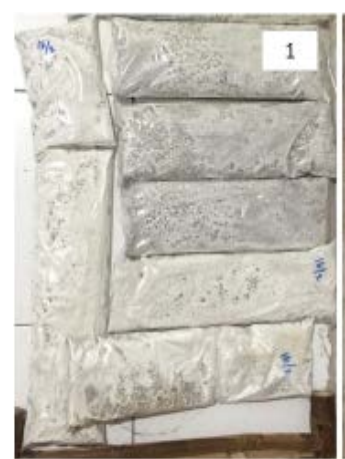

Keterangan :

1. Tempe biji kangkung dibungkus plastik
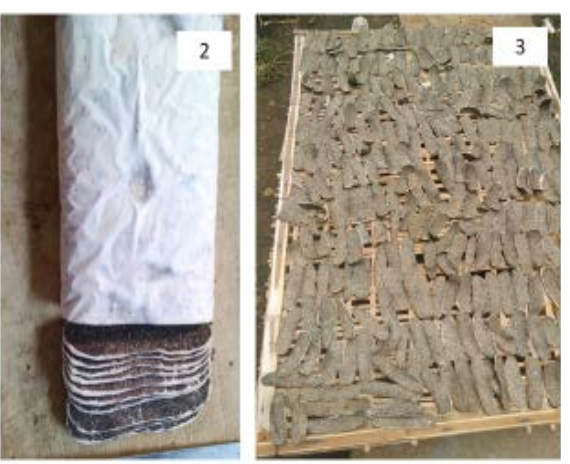

2. Tempe tampak kompak, mudah diiris

3. Irisan tempe biji kangkung, dijemur
Figure 2: Kangkong seed tempeh (1) Kangkong seed tempeh was wrapped in transparant plastic in cuboid shape; (2) Tempeh were compact and easily to sliced.

\section{EXPERIMENTAL DESIGN}

This study used 30-day old quail. Quails were subject of the completely randomized feeding experiment design consisted of 8 groups of feed ration. Each group replicated 5 times with 12 quails for each replication.

\section{QUAIL FEEDING TRIAL}

Two different types of rations were used, namely kangkong seed meal (KS) and rations containing kangkong seed meal fermentation (KSF). The nutritional and energy content of the rations was adjusted to the standards recommended by NRC (1994) which contains $20 \%$ protein and $2900 \mathrm{Kcal} /$ kg energy (Table 1).

The cage is equipped with a container for feed, drinking water, and egg. Drinking water was given ad libitum while the quail provided with 22 gram feeding material / quail/ day (NRC, 1994).

\section{OBSERVATION PARAMETERS}

The parameters observed were production performance and the physical quality of eggs. Production performance includes daily egg production (\%), egg mass, feed consumption, and feed conversion. The percentage of egg production was calculated by the equation used by Zahra et al. (2012). Feed consumption was calculated every day. Based on the method used by Maknun et al. (2015) feed consumption was calculated by reducing the feed given with the feed leftover. Feed conversion was calculated by dividing feed consumption ( $\mathrm{kg}$ ) by the number of eggs produced $(\mathrm{kg})$. Egg quality testing was done by analyzing haugh units, egg yolk color, shape index egg width/ the egg length $\times 100$, shell thickness (measured using a screw micrometer, 0.01-20 mm), (yolk index yolk weight/ yolk dimeter $\times 100$ ) albumin index (albumen weight/ albumen diamtre $\times 100$ ). The eggs were weighed one by one then cracked on flat glass and then measured its height, albumin diameter, egg yolk, and yolk color. The Haugh unit was measured through calculations according to Brant and Shrader (1958).

$$
\mathrm{HU}=100 \times \log \left(\mathrm{H}+7.57-1.7 \mathrm{~W}^{0.37}\right)
$$

Information;

$\mathrm{H}=$ albumin height $(\mathrm{mm})$ and $\mathrm{W}=$ egg weight $(\mathrm{g})$.

The yolk index was obtained from the ratio between the height and diameter of the yolk (Nesheim et al., 1979). The yolk color was adjusted according to the color index on a numerical scale from 1 to 15 (from white to red).

\section{STATISTICAL ANALYSis}

The data obtained were analyzed using analysis of variance following Completely Randomized Design (CRD) with 4 treatments and 5 repetitions for each. Based on Kolmogorov-Smirnov test all the data were normal distributed which made them as a subject of ANOVA test. A significant result then followed by Duncan's Multiple Area Test to determine the difference mean value of each feeding application.

\section{RESULTS AND DISCUSSION}

\section{FEeding PERFormance}

The average feed consumption of KS group was ranged between 21.20 to 21.60 grams/day while the KSF group between 18.45 to 18.97 grams/day. There were differences on the pattern of feed consumption between these groups as KS group showed decreased feed consumption with higher KS proportion while the KSF group showed increased feed consumption with higher KSF proportion although the difference was not significant (Table 2).

On the other hand, the feed conversion of the KS group ranged between 4.6 to 6.27 while it was 3.49 to 4.45 for KSF group. The additional proportion of KS in feeding material significantly increased the feed conversion while the addition of KSF did not show significant effect of feed conversion (Table 2).

\section{EGG PRODUCTION}

Egg production of quail decreased with increasing proportion of KS (ranged from 34.56 to $54.60 \%$ ) and KSF 
OPEN OACCESS

(ranged from 54.76 to $64.76 \%$ ) in feeding material. The differences were significant for $\mathrm{KS}$ groups while it was not significant for KSF groups (Table 3). The egg mass for both feeding groups ranged from 4-6 grams/quail/day and the weight of eggs decreased with the increasing proportion of KS and KSF. However, the differences on the egg weight were not significant for both feeding groups (Table 3).
EgG QUALITY

The average egg weight of the study ranged from 9.0610.82 grams for both feeding groups. This study showed that fed the quails with feeding material added with $7.5 \%$ of both KS and KSF produced the heaviest eggs for each related feeding group. When compared between KS and KSF groups, in general, quails received a feeding material mixed with KSF produced heavier eggs (Table 4).

Table 1: The composition of experimental diets.

\begin{tabular}{lllllllll} 
Feed ingredients & \multicolumn{2}{l}{ Proportion (\%) } & & & & & \\
& R1-KS & R2-KS & R3-KS & R4-KS & R1-KSF & R2-KSF & R3-KSF & R4-KSF \\
Corn & 51,9 & 50,9 & 50,9 & 48,9 & 39,94 & 39,94 & 39,94 & 39,94 \\
Rice bran & 9 & 5 & 0 & 0 & 10,7 & 7,2 & 3,6 & 0 \\
Coconut cake & - & - & - & - & 11,8 & 7,8 & 3,9 & 0 \\
Soybean meal & 17 & 17 & 17 & 10 & 17,5 & 17,5 & 17,5 & 17,5 \\
\hline Fish meal & 11 & 11 & 11 & 15 & 11,5 & 11,5 & 11,5 & 11,5 \\
Coconut oil & 4 & 4 & 4 & 4 & 4,5 & 4,5 & 4,5 & 4,5 \\
Bone meal & 3,5 & 3,5 & 3,5 & 3,5 & 3,5 & 3,5 & 3,5 & 3,5 \\
CaCO & 3 & 3 & 3 & 3 & 0,9 & 0,9 & 0,9 & 0,9 \\
Premix/Topmix & 0,5 & 0,5 & 0,5 & 0,5 & 0,5 & 0,5 & 0,5 & 0,5 \\
DL-Methionine & 0,1 & 0,1 & 0,1 & 0,1 & 0,16 & 0,16 & 0,16 & 0,16 \\
Lysine & 0,1 & 0,1 & 0,1 & 0,1 & 0,1 & 0,1 & 0,1 & 0,1 \\
KS & 0 & 7,5 & 15 & 22,5 & - & - & - & - \\
KSF & - & - & - & - & 0 & 7,5 & 15 & 22,5 \\
Nutrient content & & & & & & & & \\
EM (Kcal/Kg) & 2910,93 & 2910,9 & 2928,4 & 2908,7 & 2907,2 & 2929,8 & 2961,59 & 2993,39 \\
Crude protein (\%) & 20,4 & 20,46 & 20,48 & 20,03 & 20,33 & 20,42 & 20,45 & 20,21 \\
\hline Crude fat (\%) & 8,7 & 8,52 & 8,35 & 8,25 & 8,67 & 8,51 & 8,35 & 8,25 \\
\hline Crude fiber (\%) & 4,59 & 4,82 & 4,99 & 5,47 & 4,59 & 4,82 & 4,99 & 5,47 \\
Ca (\%) & 3,19 & 3,19 & 3,2 & 3,51 & 1,16 & 1,17 & 1,18 & 1,19 \\
\hline Non-phytate P (\%) & 0,88 & 0,91 & 0,94 & 1,1 & 0,6 & 0,59 & 0,58 & 0,57 \\
Methionine (\%) & 0,51 & 0,5 & 0,49 & 0,52 & 0,51 & 0,5 & 0,49 & 0,52 \\
\hline Lysine (\%) & 1,32 & 1,3 & 1,27 & 1,28 & 1,1 & 1,29 & 1,27 & 1,28
\end{tabular}

Table 2: The effect of kangkong seed meal on feeding performance.

\begin{tabular}{lllllllll} 
Variables & \multicolumn{3}{c}{ Kangkong seed meal group } & \multicolumn{3}{c}{ Kangkong seed meal fermentation Group } \\
& R1-KS & R2-KS & R3-KS & R4-KS & R1-KSF & R2-KSF & R3-KSF & R4-KSF \\
Feed consumption & $21.20 \pm 0.15 \mathrm{a}$ & $21.80 \pm 0.15 \mathrm{a}$ & $21.60 \pm 0.154 \mathrm{a}$ & $21.80 \pm 0.154 \mathrm{a}$ & $18.52 \pm 1.14 \mathrm{a}$ & $18.54 \pm 0.89 \mathrm{a}$ & $18.97 \pm 1.12 \mathrm{a}$ & $18.45 \pm 0.90 \mathrm{a}$ \\
Feed conversion & $4.6 \pm 1.34 \mathrm{a}$ & $4.99 \pm 0.37 \mathrm{ab}$ & $5.30 \pm 1.20 \mathrm{ab}$ & $6.27 \pm 1.31 \mathrm{~b}$ & $3.49 \pm 0.99 \mathrm{a}$ & $4.25 \pm 0.97 \mathrm{a}$ & $4.45 \pm 0.77 \mathrm{a}$ & $4.36 \pm 0.41 \mathrm{a}$
\end{tabular}

Table 3: The effect of kangkong seed meal on egg production.

\begin{tabular}{lllllllll} 
Variables & \multicolumn{3}{c}{ Kangkong seed meal group } & \multicolumn{3}{c}{ Kangkong seed meal fermentation Group } \\
& R1-KS & R2-KS & R3-KS & R4-KS & R1-KSF & R2-KSF & R3-KSF & R4-KSF \\
$\begin{array}{l}\text { Egg pro- } \\
\text { duction }\end{array}$ & $45.20 \pm 24.45 \mathrm{~b}$ & $42.22 \pm 3.60 \mathrm{ab}$ & $39.94 \pm 8.65 \mathrm{ab}$ & $34.56 \pm 5.86 \mathrm{a}$ & $64.76 \pm 10.56 \mathrm{a}$ & $59.52 \pm 14.86 \mathrm{a}$ & $56.28 \pm 3.98 \mathrm{a}$ & $54.76 \pm 13.03 \mathrm{a}$ \\
Egg mass & $4.79 \pm 3.22 \mathrm{a}$ & $4.40 \pm 0.36 \mathrm{a}$ & $4.26 \pm 0.93 \mathrm{a}$ & $3.62 \pm 0.73 \mathrm{a}$ & $5.49 \pm 1.10 \mathrm{a}$ & $4.64 \pm 1.10 \mathrm{a}$ & $4.71 \pm 0.29 \mathrm{a}$ & $4.59 \pm 0.92 \mathrm{a}$
\end{tabular}


Table 4: The effect of kangkong seed meal on egg production.

\begin{tabular}{|c|c|c|c|c|c|c|c|c|}
\hline \multirow[t]{2}{*}{ Variables } & \multicolumn{4}{|c|}{ Kangkong seed meal group } & \multicolumn{4}{|c|}{ Kangkong seed meal fermentation group } \\
\hline & R1-KS & $\mathrm{R} 2-\mathrm{KS}$ & R3-KS & R4-KS & R1-KSF & R2-KSF & R3-KSF & R4-KSF \\
\hline Egg weight (g) & $9.78 \pm 024 \mathrm{ab}$ & $10.03 \pm 0.18 b$ & $9.51 \pm 0.32 \mathrm{a}$ & $9.73 \pm 024 \mathrm{ab}$ & $9.06 \pm 3.98 \mathrm{a}$ & $10.82 \pm 0.47 \mathrm{a}$ & $10.76 \pm 0.38 \mathrm{a}$ & $10.52 \pm 0.48 \mathrm{a}$ \\
\hline Shape index & $81.18 \pm 1.34 \mathrm{a}$ & $82.09 \pm 1.60 \mathrm{a}$ & $82.06 \pm 1.02 \mathrm{a}$ & $81.08 \pm 1.03 \mathrm{a}$ & $81.53 \pm 1.46 \mathrm{a}$ & $78.90 \pm 1.22 \mathrm{a}$ & $80.55 \pm 0.45 a$ & $79.13 \pm 0.68 \mathrm{a}$ \\
\hline Haugh unit & $82.18 \pm 1.39 \mathrm{ab}$ & $81.78 \pm 1.52 \mathrm{a}$ & $83.68 \pm 1.39 b$ & $80.82 \pm 0.93 a$ & $81.88 \pm 3.49 a$ & $88.23 \pm 1.22 b$ & $89.28 \pm 1.13 b$ & $86.75 \pm 1.07 \mathrm{ab}$ \\
\hline $\begin{array}{l}\text { Eggshell thick- } \\
\text { ness ( } \mathrm{mm})\end{array}$ & $0.17 \pm 0.003 \mathrm{a}$ & $0.17 \pm 0.002 \mathrm{a}$ & $0.18 \pm 0.003 a$ & $0.18 \pm 0.001 \mathrm{a}$ & $0.18 \pm 0.01 \mathrm{a}$ & $0.18 \pm 0.01 \mathrm{a}$ & $0.186 \pm 0.01 \mathrm{a}$ & $0.18 \pm 0.003 a$ \\
\hline Albumen index & $0.077 \pm 0.03 \mathrm{ab}$ & $0.079 \pm 0$ & $0.081 \pm$ & 0.07 & $0.072 \pm 0.007 \mathrm{a}$ & $0.096 \pm 0.006 b c$ & & $0.084 \pm 0.006 \mathrm{ab}$ \\
\hline Yolk index & $0.485 \pm 0.09 b$ & $0.483 \pm 0.11 b$ & $0.480 \pm 0.12 b$ & $0.460 \pm 0.01 \mathrm{a}$ & $0.39 \pm 0.002 a$ & $0.44 \pm 0.001 \mathrm{a}$ & $0.42 \pm 0.001 \mathrm{a}$ & $0.432 \pm 0.002 \mathrm{a}$ \\
\hline Yolk color index & $6.30 \pm 0152 \mathrm{a}$ & $6.70 \pm 1.52 \mathrm{ab}$ & $6.90 \pm 0.10 b$ & $7.00 \pm 0.15 b$ & $6.40 \pm 0.85 a$ & $5.73 \pm 1.25 \mathrm{a}$ & $5.93 \pm 0.40 \mathrm{a}$ & $5.70 \pm 0.65 \mathrm{a}$ \\
\hline
\end{tabular}

The average shape index of eggs KS group ranged between 80.82 to 82.09 while it was between $78.90-81.53$ for KSF group. However, the shape index was not significantly differencing among groups (Table 4).

Haugh unit value is a measure of egg quality in the shell calculated from the high albumen value and egg weight. The highest Haugh unit for both KS (ranged between 81.88 to 89.28 ) and KSF (ranged between 80.82 to 83.68) groups was recorded for eggs produced by quails fed with feeding material mixed with $15 \%$ of $\mathrm{KS}$ and $\mathrm{KSF}$ and significantly different with others (Table 4).

This study showed no effect of both KS and KSF on egg thickness as both groups recorded egg thickness ranged between 0.17 to $0.18 \mathrm{~mm}$ although for KS groups application of higher proportion of KS produced slightly thicker eggshell (Table 4).

The albumin index of eggs produced quails of KSF group (ranged between 0.072 to 0.103 ), in general, higher than KS group (ranged between 0.081 to 0.074). In KS group, addition of 7.5 and $15 \%$ of KS significantly improved the albumin index while for KSF group addition of $15 \% \mathrm{KSF}$ produced significant higher albumin index (Table 4).

In general, quails of KS group produced egg with higher yolk index (ranged between 0.460 to 0.485 than KSF group (ranged between 0.39 to 0.44). Application of highest proportion of KS for feeding material produced eggs with the lowest yolk index while there was no significant effect of KSF application on yolk index (Table 4).

This study found, in general, quails of KS group produced eggs with higher yolk color index than KSF group. Additional of higher proportion of $\mathrm{KS}$ on feeding material significantly increased the yolk color index $(\mathrm{P}<0.05)$ while the effect was lacking for KSF group (Table 4).

\section{FEEDING PERFORMANCE}

In general, addition of KSF as part of feeding material reduced the consumption compared to Samadi et al. (2015) who applied the mixed of artichoke leaf flour and vitamin $\mathrm{E}$ (consumption rate of 21.40-23.24 gram/quail/ day). Quails of both KS group and KSF group as quails of KS group showed positive correlation between feed consumption, except for quails received feeding material with highest proportion of KSF. This result may relate to (1) Fermented feed produces glutamic acid which increases appetite, adds aroma and flavor that preferred by poultry. However, there is limit of the amount which indicated by lower consumption at application of higher proportion of fermented seed; (2) High fiber content of seed and non-nutritional content (such as tannins and phytic acid) may influence the feeding behavior. Fiber accelerates the digestive process, makes the rations will be released more quickly through feces, reduces the digestibility rate of the feed (Latif et al., 2017); (3) The characteristic of the feeding material may influence the consumption rate such as size, volume, and hardness of material (Amrullah, 2003; Neves et al., 2014). Other factors that may influenced the feed consumption are included the energy content of the feed, age, feed palatability, and production levels, environmental conditions, temperature, activity, the strain of poultry, and body weight (Tillman et al., 1991; Anggorodi, 1995; Wahju, 2004).

The feed conversion recorded on the quails of the study was lower than Sudrajat et al. (2014) and Suprijatna et al. (2008) while it was higher than Shanaway (1994), Achmanu et al. (2011), Bertechini (2012), Wei-Ting Hsu et al. (2015) and Fransela et al. (2017). High conversion rate is related to lower digestibility of the feeding material. The addition of kangkong seed meal in rations had a significant impact on the feed conversion value, the higher the kangkong seed meal content in the feed, the higher the conversion value for both experimental diets. Since the proximate content of KS based feeding material did not differ with KSF based feeding material, the possible explanation of higher conversion rate of KS material may relate to the characteristic of material which relative hard to digest and lower micronutrient content (unpublished data). 


\section{EGG PRODUCTION}

The production of quail eggs in this study was higher compared with study of Sudrajat et al. (2014) which applied organic chromium as part of feeding material while it was similar with study of Latif et al. (2017) which reported on the effect of application of shrimp's waste meal as part of quail feeding material.

These results on egg mass were higher than Sugiura et al. (2009) (reported the egg mass between 2.78 to 3.16 grams) and lower than Maknun et al. (2015) with values ranging from 5.43 to 6 grams/quail/day. The egg mass is strongly influenced by feed quality and protein consumption in quails (Proudfoot et al., 1988; Maknun et al., 2015). Another factor that decreases the daily egg mass is the anti-nutritional content in the feed which prevents the protein from being digested optimally (NRC, 1994).

\section{EGG QUALITY}

\section{EGG WEIGHT}

Egg weight in both treatments (KS meal and KSF meal) were greater than results from Wei-Ting Hsu et al. (2015) which supplemented quail with lycopene, Faradillah et al. (2015) which supplemented with Indigofera zollingeriana, and Hilmi et al. (2015) which supplemented with piperine. The egg weight of the results meets the standards recommended by Minvielle (1998) which is 10 grams and Tserveni-Goussi and Fortomatis (2011) which states that the weight of quail eggs ranges from 6 to 16 grams. In this study, in general, application fermented seed produced better egg which may related to the hydrolysis of protein into amino acid (Haslina and Pratiwi, 1996, Abun et al. 2003) and fatty acid which beneficial to improve the egg production (Sigolo et al. 2018).

\section{SHAPE INDEX}

The shape index of quail eggs produced in this study was higher than Zita et al. (2013) reported that the quail egg shape index was 77.35. According to Yuwanta (2010), the ideal shape index in quail egg is $74 \%$, while Kumati et al. (2008) explained that the index for quail eggs is 79.90 . The egg shape index is closely related to its hatchability as higher shape index positively related to the fertility of the eggs (MacLaury et al., 1973; Alasahan and Copur, 2016).

\section{Haugh unit}

According to Alkan (2010), the Haugh unit (HU) value describes egg quality. The haugh unit recorded in this study than Hilmi et al. (2015) reported the value of the haugh unit of quail given piperine as a feed additive, ranged from 91.81-94.45. Meanwhile, Moula et al. (2019) reported that the Haugh unit of quail egg ranging from 80.20-81.27. The differences with previous studies may relate to the age of poultry (Zita et al., 2013). However, the HU in both treatment groups meets the standard, where the $\mathrm{HU}$ value is above 72 indicates good and fresh egg quality (USDA, 2000). The higher HU of egg produced by KSF group may related to the higher variation of micronutrient produced by fermentation process.

\section{SHELl THiCKNesS}

Previous study showed the variation of quail eggshell thickness ranged from $0.12-0.19 \mathrm{~mm}$ (Panda and Singh, 1990; Amo et al., 2013; Zita et al., 2013; Moula et al., 2019; Pâmela et al., 2019) which in range of the eggshell thickness produced during this study. Shell thickness showed could be significantly improved, higher than 0.19 $\mathrm{mm}$, by supplementation of commercial feed and low protein ration (Suprijatna et al., 2008). Another factor related to the development of eggshell is the balance of calcium $(\mathrm{Ca})$, phosphoros $(\mathrm{P})$, and magnesium in the feeding material (King'ori, 2011; Amoah et al., 2012). However, in this study, both variable was not recorded. Thus, the conclusion based on our data was the high possibility that the fermentation process did not alter the balance of the mineral of the feeding material.

\section{AlBumEn, YOLK INDEX, AND YOLK COLOR INDEX}

The albumen index value of the two experimental diets was higher than Moula et al. (2019) that reported the albumin index were ranged from $0.057-0.059$. This study showed higher albumen index produced by quail of KSF group. On the other hand, the yolk index. The results of the study were not much different from Moula et al. (2019) that reported the yolk index value of quail were ranged from $0.432-0.434$. The yolk index of quail fed with KSF meal is in the second category of SNI $(0.394-0.457 \mathrm{~mm})$, and category I (0.458-0.521 mm) for quail fed with KS meal. Higher yolk index Quail fed with KS meal had a higher egg yolk index, although it tended to decrease with increasing kangkong seed contents in the ration. Yolk and albumin content highly depend on the nutritional content of the feeding material especially particular fatty acid like omega 3 and omega 6 (Alagawany et al., 2019). Studi showed fermentation may reduce the available of some fatty acid which may explained why the yolk and albumin index of eggs of KSF group lower than KS group (Oduguwa et al., 2008; Silveira et al., 2010).

The higher the KS meal in the ration produced higher the egg yolk color index. The yolk color index of the two experimental diets was lower than Hilmi et al. (2015) reported that the yolk color index of quail ranged from 7.53-8.98. It is stated by as well as Lee et al. (2001) the darker color of egg yolk is exclusively influenced by feed because poultry does not synthesize color pigments but only absorbs $20-60 \%$ of feed pigment. The major nutritional component that effected the yolk color is carotenoid content of the feed ingredient (Amo et al., 2013) which stored inside the seed. Fermentation process 
more likely to release the carotenoid to utilize by microbes or to environment as byproduct which may altered by the feeding material preparation process.

\section{CONCLUSIONS AND RECOMMENDATIONS}

Kangkong seed meal (KS) and its fermentation product (KSF) did not enhance the performance of the egg production of quails but improved some physical egg quality. KSF meal had a better effect than kangkong meal on egg production performance, feed conversion, shell thickness, albumen index, and Haugh unit. While KS meal increased the shape index, yolk index, and yolk color index.

\section{ACKNOWLEDGMENTS}

The authors gratefully thank all colleagues in the department for their technical assistance during laboratory analysis and provide insight and expertise that greatly assisted the research.

\section{NOVELTY STATEMENT}

This research is the first study on the use of kangkong seed waste for quail and other poultry. The nutritional value of kangkong seeds was also increased by fermentation. Both were compared and used as a substitute for quail feed ingredients and observed their effect on production performance and egg quality. We hope that this journal will provide further knowledge about the use of agricultural waste, especially kangkong seed waste for poultry feed.

\section{AUTHOR'S CONTRIBUTION}

Astuti Kusumorini presents the research idea and conducts the research. Denny Rusmana helped to determine the experimental design and verified the research methods. Ana Rochana formulates the nutrition for quail rations. Astuti Kusumorini and Ramadhani Eka Putra wrote the manuscript with the guidance and supervision of Ana Rochana and Denny Rusmana. All authors contributed to writing this manuscript.

\section{CONFLICT OF INTEREST}

The authors have declared no conflict of interest.

\section{REFERENCES}

-Abun D, Rusmana, dan NP, Indriani (2003). Determination of digestibility of ration containing garut bulbs (Maranta arundinacea Linn.) in broiler chicken with cutting method. J. Bionatura., 5(3): 227-238.

-Achmanu, Muharlien, Salaby (2011). Effect of Cage Floor
(Slat and Litter) and Sex Ratio on Feed Consumption, Egg Weight, Feed Conversion and Thickness of Eggshell in Quail. Ternak Tropika, 12(2): 1-14.

-Alagawany M, Shaaban S, Elnesr, Mayada R, Farag, Mohamed E, Abd El-Hack, Asmaa F, Khafaga, Ayman E, Taha, Ruchi TM, Iqbal Y, Prakash B, Sandip KK, Kuldeep D (2019). Omega-3 and Omega-6 Fatty Acids in Poultry Nutrition: Effect on Production Performance and Health, Animals (Basel), 2019 Aug; 9(8): 573.

-Alasahan S, Copur AG (2016). Hatcing characteristic and growth performance of egg with differnt egg shapes. Braz.J. Poult. Sci., ISSN 15116-635X

-Alkan SK, Karabag A, Galic T, Karsli MS, Balcioglu (2010). Effects of selection for body weight and egg production on egg quality traits in Japanese quails (Coturnix coturnix japonica) of different lines and relationships between these traits. Kafkas Univ. Vet. Fak. Derg., 16(2): 239-244.

-Amo M, Saerang JLP, Najoan M, Keintjem J (2013). Pengaruh Penambahan Tepung Kunyit (Curcuma Domestica Val) dalam Ransum terhadap Kualitas Telur Puyuh (Coturnix-coturnix Japonica). J. Zootek, 33(1): 48-57.

-Amoah JK, Martin EA, Barroga AJ, Garillo EP, Domigo I (2012). Calcium and phosphorus requirements of Japanese quail layers. J. App. Biosci., 54: 3892-3900.

-Amrullah IK (2003). Nutrisi ayam petelur. Penerbit Lembaga Satu Gunung Budi, Bogor, Indonesia.

-Anggorodi HR (1995). Nutrisi Aneka Ternak Unggas. Gramedia Pustaka Utama, Jakarta, Indonesia.

-Aro SO (2008). Improvement in the nutritive quality of cassava and its by-products through microbial fermentation. Afr. J. Biotechnol., 7(25): 4789-4797.

-Arthur, Jennifer, Bejaei M (2017). Quail egg: Egg innovations and strategies for improvements. Academic Press Elsivier. Massachusets, USA.

- Benedetti MP, Sartori JR, Carvalho FB., Pereira LA, Fascina VB, Stradiotti AC, Pezzato AC, Costa C, Ferreira JG (2011). Corn texture and particle size in broiler diets. Rev. Bras. Cienc. Avic. 13 (4) : 227-234.

-Bertechini AD (2012). The quail production CD Paper in proceedings of the XXIV World's poultry congress, Salvador, Brazil. Worlds. Poult. Sci. J., 68 (Suppl. 1),4.

-Bologa M, Pop IM, Albu A (2013). Research on the chemical composition of chicken egg from different system of production (conventional and organic). Seria Medicina Veterinaria, 59(1): 80-85.

- Brant AW, Shrader HL (1985). Equipment and methods for measuring egg quality. Department of Agriculture, Washington DC, USA.

- da Cunha RGT (2009). Quail meat an undiscovered alternative. World Poult., 25: 12-14.

-Directorate General of Livestock and Animal Health (2020). Quail Population According to Population. Ministry of Agriculture of the Republic of Indonesia, Jakarta, Indonesia.

-Directorate General of PPHP (2014). Statistics of export import of agricultural commodities 2001-2013. J. Agric. Commod. Exp. Imp. Stat., Jakarta, Indonesia.

-El-Daly EF, El-Wardany I, El-Gawad AHA, Hemid AEA, El-Azeem NAA (2013). Physiological, Biochemical and Metabolic Responses of Japanese Quail (Coturnix coturnix japonica) as affected by early heat stress and dietary treatment. Iran J. Appl. Anim. Sci., 13(3): 207-216.

-Elnesr SS, Ropy A, Abdel-Razik AH (2019). Effect of dietary sodium butyrate supplementation on growth, blood 
biochemistry, hematology, and histomorphometry of intestine and immune organs of Japanese quail. Animal, 13(6): 1234-1244.

- Faradillah F, Mutia R, Abdullah L (2015). Substitution of soybean meal with Indigofera zollingeriana top leaf meal on egg quality of Cortunix Cortunix Japonica. Media Peternakan. 38(3): 192-197.

- Food and Agriculture Organization of the United Nations (2013). Edible insects future prospects for food and feed security. FAO Forestry, Rome, Italy.

- Fransela TCLK, Sarajah MER, Montong, Najoan M (2017). Performance of quail (Coturnix- coturnix japonica) provided conch paddy (Pila Ampullacea) flour as a substitute for fish flour in the ration. J. Zootek, 37(1): 62-69.

- Grela ER, Ognik K, Czech A, Matras J (2014). Quality assessment of eggs from laying hens fed a mixture with lucerne protein concentrate. J. Anim. Feed Sci., 23(3): 236243.

- Haslina dan E, Pratiwi (1996). Benefits of tempe for nutrition and human health. Sainteks, 3(4): 45-51.

- Hilmi M, Sumiati, Astut DA (2015). Egg production and physical quality in Cortunix coturnix japonica fed diet containing piperine as phytogenic feed additive. Media Peternakan, 38(3): 150-155.

- King'ori, Anthony. (2011). Review of the factors that influence egg fertility and hatchabilty in poultry. Int. J. Poult. Sci. 10. 483-492.

- Kumari PB, Ramesh GB, Gnana PB, Rajasekhar RA (2008). A study on eggs quality traits in Japanese quail (Coturnix coturnix japonica) Tamilnadu. J. Vet. Sci., 4: 227-231.

- Latif S, Suprijatna E, Dwi Sunarti (2017). The performance of quail's which is given ration of fermented shrimp waste flour. J. Ilmu-Ilmu Peternakan, 27(3): 44-53.

-Lee BD, Kim DJ, Lee SJ (2001). Nutritive and economic values of high oil corn in layer diet. Poult. Sci., 80(11): 1527-1534.

-Machal L, Simeonovová J (2002). The relationship of shortening and strength of eggshell to some egg quality indicators and egg production in hens of different initial laying lines. Arch. Tierzucht, Dummerstorf, 45(3): 287-296.

- MacLaury DW, Insko WM JR., Begin JJ, Johnson TH (1973). Shape index versus hatchability of fertile egg of Japanese quail (Coturnix coturnix japonica). Poult. Sci., 52: 558-562.

- Maknun L, Sri K, Isna M (2015). Performans produksi burung puyuh (Coturnix coturnix japonica) dengan perlakuan tepung limbah penetasan telur puyuh. J. Ilmu-ilmu Peternakan, 25(3): 53-58.

- Minvielle F (1998). Genetics and breeding of Japanese quail for production around the world. Proc. $6^{\text {th }}$ Asian Pac. Poult. Cong. Nagoya, Japan, pp. 122-127.

- Moula N, Sadoudi A, Touazi L, Leroy P, Geda F (2019). Effects of stinging nettle (Urtica dioica) powder on laying performance, egg quality, and serum biochemical parameters of Japanese quails. Anim. Nutr., 5(4): 410-415.

- National Research Council (1994). Nutrient requirement of poultry. Revised Edition. National Academy Press, Washington DC, USA.

-Nesheim MC, Austic RE, Card LE (1979). Poultry production (12 ${ }^{\text {th }}$ ed.). eae Febiger, Philadelphia, USA.

- Neves DP, Banhazi TM, Naas IA (2014). Feeding behavior of broiler chickens: A riview on the biomechanical characteristics. Braz. J. Poult. Sci., ISSN 15116-635X.

- Oduguwa OO, Edema MO, Ayeni AO (2008). Physicochemical and microbiological analyses of fermented corn cob, rice bran and cowpea husk for use in composite rabbit feed. Bioresour. Technol., 99(6): 1816-1820.

- Pâmela LR, das Nevesb DG, Bernardesb LF, de Rezende Limab D, Ribeirob CB, Gonçalvesb NC, Alvarengab RR, Fassanib EJ, Zangeronimoa MG (2019). Reproductive characteristics of male and female Japanese quails (Coturnix coturnix japonica) fed diets with different levels of crude protein during the growth and production phases. Livest. Sci.. 223(19): 124-132.

- Panda B, Singh RP (1990). Developments in processing quail meat and eggs. Worlds Poult. Sci. J., 46: 219-234.

- Proudfoot FG, Hulan HW, McRae KB (1988). Performance comparisons of phased protein dietary regimens fed to commercial Leghorns during the laying period. Poult. Sci., 67: 1447-1454.

- Runjaic AD, Pavkov S, Levic J (2010). Herbs in sustainable animal nutrition. Biotechnol. Anim. Husb., 10(26): 203214.

-Samadi F, Sahneh M (2015). Effects of artichoke (Cynara scolymus L.) Leaf Meal and Vitamin E on Productive Performance, Intestinal Microflora and Morphology in Japanese Quail. Poult. Sci. J., 3(1): 87-98.

- Sezer M (2007). Heritability of exterior eggs quality traits in Japanese quail. J. Appl. Biol. Sci., 1: 37-40.

-Shanaway MM (1994). Quail production systems: A review. Food and Agriculture Organization of the United Nations. Food and Agriculture Organization of the United Nations, Rome, Italy.

- Sigolo S, Roshanak K, Alireza S, Antonio G, Aldo P (2018). Effect of Supra-nutritional level of vitamin $E$ and vitamin $C$ on growth performance and egg production trait of Japanese quails. Ital. J. Anim. Sci., Volume 18-Issue 1.

- Silveira CM, Oliveira MS, Badiale-Furlong E (2010). Lipid content and fatty acid profile of defatted rice bran and wheat bran submitted to solid state fermentation by Aspergillus oryzae. Bol. CEPPA, 28(1): 133-140.

- Sudrajat D, Kardaya D, Dihansih E, Puteri SFS (2014). Production performance of quails given chromium organic in the ration. JITV., 19(4): 257-262.

- Sugiura K, Fushimi K, Takehisa T, Miwa M, Saito T, Uchida Y, Onodera T (2009). An outbreak of H7N6 low pathogenic avian influenza in quails in Japan. Vet. Ital., 45: 481-489.

-Supartini, Nonok (2009). Penggunaan Pollard dengan Asam Amino Sintesis Dalam Pakan Ayam Petelur Upaya Terhadap Peningkatan Kualitas Fisik Telur. Buana Sains, 9(1): 17-23.

-Tillman AD, Hartadi H, Reksohadiprojo S (1991). Ilmu makanan ternak dasar. UGM Press, Yogyakarta, Indonesia.

-Tolik D, Polawska E, Charuta A, Nowaczewski S, Cooper R (2014). Characteristics of egg parts, chemical composition, and nutritive value of Japanese quail eggs. Folia Biologica (Krakow). 62: 287-292.

-Tserveni-Goussi A, Fortomaris P (2011). Production and quality of quail, pheasant, goose, and turkey eggs for uses other than human consumption. Woodhead Publishing, United Kingdom. https://doi.org/10.1533/9780857093912.4.509

- United States Department of Agriculture (USDA) (2000). Egg Grading Manual. Agricultural Handbook Number 75, Washington DC, USA.

-Wahju J (2004). Ilmu Nutrisi Unggas. Gadjah Mada University Press,Yogyakarta, Indonesia.

-Wei-Ting H, Chung-Jen C, Yun-Peng C, Chi-Huan C, LiJen L, Bi Y, Tzu-Tai L (2015). Effects of recombinant lycopene dietary supplement on the egg quality and blood 
characteristics of laying quails. J. Biosci. Bioeng., 10(10): 1-5.

-Yuwanta T (2010). Telur dan kualitas telur. Gajah Mada University Press, Yogyakarta, Indonesia.

-Zadeh ZS, Farshid K, Mostafa F (2019). Use of yellow mealworm (Tenebrio molitor) as a protein source on growth performance, carcass traits, meat quality, and intestinal morphology of Japanese quails (Coturnix japonica). Vet.
Anim. Sci., 8: 100066.

-Zahra AA, Sunardi D, Suprijatna E (2012). Effects of Free Choice Feeding on The Egg Production Performance Of Coturnix coturnix japonica. Anim. Agric. J., 1: 1-11.

-Zita L, Ledvinka Z, Klesalova L (2013). The effect of the age of Japanese quails on certain egg quality traits and their relationship. Vet. Arhiv., 83: 223-232. 